Article

\title{
Transitioning European Protein-Rich Food Consumption and Production towards More Sustainable Patterns-Strategies and Policy Suggestions
}

\author{
Rhys Manners ${ }^{1, *}$, Irene Blanco-Gutiérrez ${ }^{2,3}$, Consuelo Varela-Ortega ${ }^{2,3}$ and Ana M. Tarquis ${ }^{3,4}$ \\ 1 International Institute of Tropical Agriculture (IITA), KG 563 Kigali, Rwanda \\ 2 Department of Agricultural Economics, Statistics and Business Management, ETSIAAB, Universidad \\ Politécnica de Madrid (UPM), Av. Complutense s/n, 28040 Madrid, Spain; irene.blanco@upm.es (I.B.-G.); \\ consuelo.varela@upm.es (C.V.-O.) \\ 3 CEIGRAM, Universidad Politécnica de Madrid (UPM), C/ Senda del Rey 13, 28040 Madrid, Spain; \\ anamaria.tarquis@upm.es \\ 4 Department of Applied Mathematics, ETSIAAB, Universidad Politécnica de Madrid (UPM), \\ Av. Complutense s/n, 28040 Madrid, Spain \\ * Correspondence: r.manners@cgiar.org
}

Received: 26 January 2020; Accepted: 29 February 2020; Published: 4 March 2020

\begin{abstract}
Global and European diets have shifted towards greater consumption of animal proteins. Recent studies urge reversals of these trends and call for a rapid transition towards adoption of more plant-based diets. This paper explored mechanisms to increase the production and consumption of plant-proteins in Europe by 2030, using participatory backcasting. We identified pathways to the future (strategies), as well as interim milestones, barriers, opportunities and actions, with key European stakeholders in the agri-food chain. Results show that four strategies could be implemented to achieve the desired future: increased research and development, enriched consumer education and awareness, improved and connected supply and value chains and public policy supports. Actions needed to reach milestones were required immediately, reinforcing the need for urgent actions to tackle the protein challenge. This study concretely detailed how idealized dietary futures can be achieved in a real-world context. It can support EU protein transition by informing policy makers and the broader public on potential ways to move towards a more sustainable plant-based future. The outputs of this analysis have the potential to be combined with dietary scenarios to develop more temporally explicit models of future dietary changes and how to reach them.
\end{abstract}

Keywords: future; meat substitution; plant proteins; stakeholders; backcasting; pathways

\section{Introduction}

A number of studies conclude that increases in animal protein production and consumption are unsustainable, contributing to degraded natural systems, biodiversity losses and climate change [1-5]. These changes are also implicated in an array of human health issues [6-8]. Global consumption of animal products has increased by almost 30\% since 1961, whilst plant protein consumption has largely reduced $[9,10]$. Animal-proteins now account for at least $40 \%$ of dietary proteins $[11,12]$. These dietary changes are the manifestation of socio-economic transitions towards wealthier and urban populations [13-17]. These patterns are widely expected to continue, even in wealthier regions $[16,17]$. The impacts of these trends have led to suggestions that without future targeted dietary changes, the associated environmental and health impacts will be grave (e.g., Etemadi et al. [6], 
Springmann et al. [18]). These predictions have led to calls for sustainable diets rich in plant-based proteins to be encouraged (e.g., Willett [2], Springmann et al. [18], IPCC [19]).

The potential for reversing current dietary trends and replacing animal proteins with plant proteins has been widely studied $[11,20,21]$. Adoption of the 'Mediterranean,' vegetarian or vegan diets have all been proposed as mechanisms for achieving such reversals $[2,18,22,23]$. The benefits of shifts towards diverse and largely plant-based diets could address the negative impacts of current dietary trends by reducing dietary based emissions, supplying adequate calories for growing global populations, averting diet related avoidable deaths and reducing agriculturally driven deforestation $[2,18,22,23]$. However, despite the considerable benefits that could be accrued from plant-based diets, they represent significant societal and agricultural systemic changes, with dramatic shifts in consumer attitudes needed $[8,24,25]$. Although consumer attitudes have shifted and increases in vegetarianism have been observed in wealthier countries $[25,26]$, further shifts are still required to attain the idealized futures described in the literature (e.g., Springmann et al. [21]).

These observations evidence a divergence in outlooks of the future, where idealized futures $[18,22]$ are compared to business-as-usual projections [17]. The process of reaching idealized future conditions are often considered through dietary scenarios, where narrow mechanisms (e.g., meat taxation) and their impacts (e.g., reduced meat consumption) are analyzed (e.g., Springmann et al. [21], Cassidy et al. [22], Erb et al. [23]). The utility of such methods is unquestionable for framing the human health and environmental argument for dietary change and potential future conditions [27]. However, scenario-based analyses, in general, consider only limited variables, ignoring the wider challenges of how contemporary social and agricultural systems transition to a point where the idealized future becomes a societal reality [28].

Characterization of potential strategies and the policy environments required to encourage and enable such wide-ranging systemic changes remain comparatively unexplored. A number of recent studies have begun addressing this, characterizing how consumption shifts could be made through education and policy interventions over time $[29,30]$. But their narrow focus ignores the wider social, agricultural and political environments within which these changes would need to be made. Graça et al. [31] go a step further, developing a framework for mapping the socio-economic barriers and enablers, which may discourage/encourage future dietary shits. Although this work is vital, it largely considers only one side of the problem- consumption. However, for dietary transitions to be made, simultaneous changes in production would also be needed. This therefore offers an opportunity to investigate how society and in particular high animal-protein consuming regions, like Europe, can address current trends and move towards the idealized futures envisaged in the literature. In particular, considering mechanisms and pathways for encouraging both increased consumption and production of plant proteins.

To do so, we propose a participatory methodology to characterize pathways from the present towards an idealized dietary and production future, where plant-proteins are consumed and produced at the expense of animal proteins. In investigating idealized futures, the development of participatory normative scenarios (or backcastings) can be useful [32]. Participatory backcasting offers a framework for medium to long-term planning that includes development of mechanisms and strategies required for attaining desirable futures [33,34]. It is normative, goal-oriented and problem-solving and is characterized by involvement of heterogeneous stakeholders contributing to a consensual visioning [35].

This analysis looks to: (i) understand the barriers and opportunities that may inhibit or enable dietary and production changes in the future; (ii) map policy actions and milestones needed to achieve a sustainable future; iii) develop stakeholder developed strategies for moving towards this sustainable future. This novel study ultimately aims to inform visionary policy-making about future strategies and possible shifts in consumption and production of proteins across the EU towards a more sustainable future and hopefully provide the impetus for future studies to provide greater detail to these strategies. 


\section{Methodology}

\subsection{Context}

This analysis has been developed within a five-year European research project: 'PROTEIN2FOOD' ( Development of high quality food protein through sustainable production and processing. Project No. 635727-2. Horizon 2020 Programme, under the Societal Challenge 2-Food Security, Sustainable Agriculture and Forestry, Marine, Maritime and Inland Water Research and the Bioeconomy. EU Commission, 2015-2020.). The project aims to develop innovative, high quality, protein-rich crops and food products to sustain human health, the environment and biodiversity and help transition to more sustainable food systems in Europe. Stakeholders play a crucial role in the project forming a 'stakeholder forum,' an advisory body to the project. Stakeholder forum meetings are organized annually to gather stakeholders and partners to facilitate discussion about the project and future prospects. This study is devoted to the analysis of the results obtained in the 3rd Stakeholder Forum meeting, held in Freising, Germany, in March 2018. More information of the PROTEIN2FOOD and the stakeholder forum and workshops can be found in Appendix A 'The Project.'

\subsection{Backcasting}

The backcasting technique can be used to develop normative visions of the future [33]. It can assist in planning and decision-making by exploring the conditions required for realization of idealized visions [34]. It also presents the opportunity to explore the feasibility of alternative future conditions and formulate solutions for their achievement [36]. Including stakeholders as part of this technique allows them to work backwards from agreed end-points and outline barriers and opportunities, define milestones and describe actions required for the achievement of idealized end-points [37]. Backcasting can liberate stakeholders of the constraints of contemporary thinking, offering greater freedom in developing more creative solutions [38]. Stakeholder engagement can also expand the knowledge base and provide an opportunity for social learning [39], increase legitimization of outputs and allow for consensus building [40]. As an output, strategies from the future to the present can be mapped and characterized, aiding in planning processes [36].

Participatory backcasting can be developed following variants of the five steps (e.g., Kok et al. [36]) presented in Table 1:

Table 1. Methodological steps of participatory backcasting.

\begin{tabular}{|c|c|}
\hline Step & Activities \\
\hline $\begin{array}{l}\text { 1: Defining a } \\
\text { desirable future }\end{array}$ & $\begin{array}{l}\text { Backcasting starts defining and describing the desired future in which the problems identified are } \\
\text { expected to be solved by meeting a stated objective. Participants determine the spatial and temporal } \\
\text { scale of the analysis and agree upon the final end-point (objective) of the backcasting and its timeline. }\end{array}$ \\
\hline $\begin{array}{l}\text { 2: Identifying } \\
\text { milestones }\end{array}$ & $\begin{array}{l}\text { Milestones are interim objectives that are required to achieve the desired objective from Step } 1 . \\
\text { Participants are asked to identify milestones and place them on a backcasting timeline (line from the } \\
\text { year of the objective to the present). Also, they are invited to specify why the milestone is needed, what } \\
\text { it entails and when it needs to be achieved. }\end{array}$ \\
\hline $\begin{array}{l}\text { 3: Identifying barriers } \\
\text { and opportunities }\end{array}$ & $\begin{array}{l}\text { Barriers and opportunities for achieving the objective and milestones are identified (Steps } 1 \text { and } 2 \text { ). } \\
\text { Participants are given the opportunity to present factors or processes that they consider to be a barrier } \\
\text { for achieving the objective or milestones. Similarly, opportunities that can be taken advantage of to } \\
\text { achieve the objective and the interim milestones are defined. As with the milestones, participants are } \\
\text { asked to explain the barrier/ opportunity to other participants and then place it on the backcasting } \\
\text { timeline. }\end{array}$ \\
\hline 4: Identifying actions & $\begin{array}{l}\text { Participants are then invited to identify actions that are required to achieve the objective (Step 1) and } \\
\text { milestones (Step 2), address the barriers or take advantage of the opportunities (Step 3). Participants are } \\
\text { asked to describe the action and place it upon the backcast timeline. Likewise, they are requested to be } \\
\text { as specific as possible, specifying what the action would entail, who would enforce them and when they } \\
\text { would be implemented. }\end{array}$ \\
\hline 5: Defining strategies & $\begin{array}{l}\text { Participants are then asked to develop pathways from the desired future objective back to the present. } \\
\text { Milestones are connected with the policy actions that would be required for their achievement. } \\
\text { These pathways connecting milestones and actions are called strategies. }\end{array}$ \\
\hline
\end{tabular}




\subsection{Stakeholder Workshop}

The backcasting exercise was implemented as part of PROTEIN2FOOD during the 3rd stakeholder forum meeting. The stakeholder forum meeting consisted of a one-day workshop of 37 participants, which included key researchers from the project and representatives of the food production-processing-consumption chain (Table 2).

Table 2. Stakeholder workshop: Groups and participants.

\begin{tabular}{|c|c|c|c|}
\hline Group & No. of Participants & Countries Represented & Stakeholder Groups Represented \\
\hline 1 & 19 & $\begin{array}{l}\text { Denmark, France, } \\
\text { Germany, Ireland, Italy, } \\
\text { Netherlands, Spain, } \\
\text { Sweden, Romania, UK }\end{array}$ & $\begin{array}{c}\text { Researchers, raw product producers, } \\
\text { agricultural consultants, raw product } \\
\text { traders, product transformation and } \\
\text { development industry, final product } \\
\text { industry, NGO }\end{array}$ \\
\hline 2 & 18 & $\begin{array}{l}\text { Belgium, Denmark, } \\
\text { France, Germany, } \\
\text { Ireland, Italy, } \\
\text { Netherlands, Poland, } \\
\text { Spain, UK }\end{array}$ & $\begin{array}{l}\text { Researchers, raw product producers, } \\
\text { product marketing, product } \\
\text { transformation and development } \\
\text { industry, nutrition communication } \\
\text { consultants }\end{array}$ \\
\hline
\end{tabular}

The workshop included short plenary presentations on the EU plant-protein food challenge, the backcasting exercise and a final wrap-up discussion chaired by a research EU Policy Officer. The backcasting exercise was developed following the steps described in Table 1. Step 1 (defining a desirable future) was completed in a plenary session with all participants agreeing on a common desired future objective. Then, two groups of 18 and 19 participants were formed to develop Steps 2 to 5 (identification of milestones, barriers, opportunities, policy actions and strategies). As much as possible, the two groups were equally balanced in terms of stakeholder group and geographical representation (see Table 2). Steps 2 to 5 were simultaneously performed across the two groups to facilitate the process of developing backcasting maps and to explore alternative visions of how to reach the desired endpoint. As part of Step 4 (identifying policy actions), participants were asked to vote on which policy action was most needed to achieve the final objective. This voting was also weighted, with participants giving three votes to the most important, two votes to second and one to the third.

As a result, two backcasting maps were produced. A summary overview in the form of strategies and most voted options was presented and discussed in the final wrap-up session.

\subsection{Analysis}

The two backcasting maps were comparatively analyzed in terms of structure and contents. The structure of the backcasts was analyzed using basic graph theory. To do so, the backcast maps were interpreted as graphs, which are mathematical structures that represent pairwise relationships between elements. We used Latapy et al. [41] as a basis to study the spatial structure (composition) of the maps (type and number of elements; barriers, opportunities, milestones and actions and links between them). As part of this analysis, two parameters were created: (i) ' $\mathrm{M}+\mathrm{A}^{\prime}$ that represents the sum of milestones and actions and is considered a proxy for measuring the proactivity and response to change of the system (backcast); and (ii) 'O- $\mathrm{B}$ ' is the number of opportunities minus the barriers and is used as a proxy to measure the resistance to change of the system (backcast). Following Wu et al. [42], we also studied the temporal structure of the maps, in particular, the evolution of elements and links across time. The content of the backcasts was analyzed by looking across maps identifying different and common elements (milestones, barriers, opportunities, actions) and strategies. We used Kok et al. [36] to compare strategies and identify robust (common) strategies and policy suggestions. Strategies were considered robust if the themes they covered and the general content were identified in both groups. 


\section{Results}

\subsection{Desired Future}

Stakeholders agreed on the following desired end-point (objective): "To increase plant-protein production and consumption (by 25\% and 10\%, respectively) in the EU by 2030." This objective coincides with one of the key expected results of the PROTEIN2FOOD project. Participants believed that the project could incentivize protein crop production and consumption in the EU by developing new breeding techniques, optimizing crop and soil management methods and identifying appropriate market approaches. The new plant protein food ingredients and products developed in the project were expected to receive a high consumer acceptance, leading to a gain market share of these types of products and a reduction of meat consumption in the medium to long term. Meeting the desired objective was considered crucial to enhance protein transition from animal-based to plant-based protein and thus, promote a more sustainable plant-rich diet in the EU.

A period of 15 years (2015-2030) was selected for the backcast timeline. The year 2030 was chosen as the reference point for the future due to the time horizon of the PROTEIN2FOOD project, its temporal proximity to facilitate participants' ability to imagine a future and to coincide with the targets of relevant policies and initiatives, such as the UN's 2030 Agenda for Sustainable Development and the EU's FOOD 2030. Researchers and policy makers have become increasingly more aware that dietary change is central to meet the proposed Sustainable Development Goals (SDGs) (2, 16 and 17) [43] and the Paris Climate Change Accord [19].

\subsection{Backcasting 'maps' Structure}

In total, 146 elements were generated across the two backcasts, with 82 (56\% of the total) developed in the first group and 64 (44\% of the total) in the second (Table 3). In general, elements were evenly distributed across groupings (milestones, barriers, opportunities and actions). Actions represent the largest number of elements, followed by milestones. Full backcasts can be found in the Appendix A (Figures A1 and A2).

Table 3. Elements identified in the backcasting maps of Group 1 and 2.

\begin{tabular}{cccccccccc}
\hline \multirow{2}{*}{ Group } & \multicolumn{2}{c}{ Milestones } & \multicolumn{2}{c}{ Barriers } & \multicolumn{2}{c}{ Opportunities } & \multicolumn{2}{c}{ Actions } & \multicolumn{2}{c}{ Total Elements } \\
\cline { 2 - 9 } & $\mathbf{N}$ & $\mathbf{\%}$ & $\mathbf{N}$ & $\mathbf{\%}$ & $\mathbf{N}$ & $\mathbf{\%}$ & $\mathbf{N}$ & $\mathbf{\%}$ & $\mathbf{N}$ \\
\hline 1 & 19 & 22 & 19 & 24 & 18 & 22 & 26 & 32 & 82 \\
2 & 18 & 28 & 17 & 27 & 15 & 23 & 14 & 22 & 64 \\
\hline Total & 36 & 25 & 36 & 25 & 33 & 23 & 40 & 27 & 146 \\
\hline
\end{tabular}

The temporal positioning of elements was not evenly distributed (Table 4). Most elements were placed in the present (2015-2020) and the near future (2021-2025), with few elements placed in the most distant period (2026-2030). In Group 1, 39 elements (48\% of the total) were included in the present (2015-2020), 30 (36\%) in the near future (2021-2025) and 13 (17\%) in the long-term future (2026-2030). Similarly, in Group 2, the present concentrates most of the elements (29,45\% of the total), followed by the near future $(25,39 \%$ of the total) and the long-term future $(10,16 \%$ of the total).

Looking at the type of elements and their location on the timeline (Table 4), barriers were found in the present (2015-2020), actions in the present and near future (2015-2025) and opportunities and milestones more evenly distributed. Figures 1 and 2 show that, in the period covering the near past-present (2015-2020), barriers outnumber opportunities (O-B presents negative values), particularly in Group 2, which illustrate the difficulty to change the current situation. After 2020, stakeholders perceive a brighter future, with more opportunities than barriers ( $\mathrm{O}-\mathrm{B}$ positive values) and thus suggest less resistance to change. In both groups, barriers reduce to zero at the end of the period (2026-2030) but this is more noticeable in Group 1, where no barriers were identified after 2024. This may be explained 
by current barriers being more evident than those of the future. Years 2022-2023 and 2027-2030 are quite neutral, with the same number of opportunities and barriers (O-B is equal to zero).

Table 4. Temporal positioning of elements identified in the backcasting maps of Group 1 and 2.

\begin{tabular}{ccccccc}
\hline Group & Timeline & Milestones & Barriers & Opportunities & Actions & Total Elements \\
\hline \multirow{3}{*}{1} & $2015-2020$ & 6 & 14 & 7 & 12 & 39 \\
\cline { 2 - 7 } & $2021-2025$ & 8 & 5 & 8 & 9 & 30 \\
\cline { 2 - 7 } & $2026-2030$ & 5 & 0 & 3 & 5 & 13 \\
\hline \multirow{2}{*}{2} & $2015-2020$ & 6 & 12 & 4 & 7 & 29 \\
\cline { 2 - 7 } & $2021-2025$ & 8 & 3 & 8 & 6 & 25 \\
\hline
\end{tabular}

The proactive response to change, measured by the sum of milestones and actions $(M+A)$, presents a more irregular and oscillatory pattern compared with the resistance to change (O-B) (Figures 3 and 4). Notably in Group 1, years with high $\mathrm{M}+\mathrm{A}$ values are preceded and followed by years with low $\mathrm{M}+\mathrm{A}$ values. In general, however, the present and near future (2015-2025) include high M+A values, suggesting stakeholders perceive that immediate action is required. The most distant period of time (2026-2030) shows low M+A values (e.g., in Group 2, neither actions nor milestones were defined in year 2027). Thus, how to act in the future is less clear in the eyes of stakeholders.

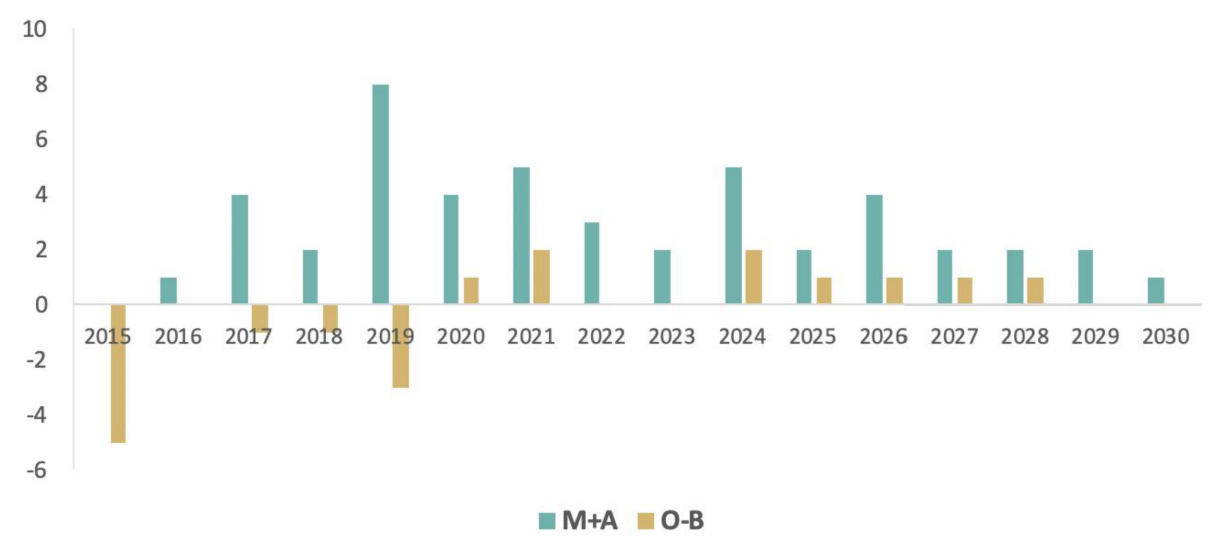

Figure 1. Balance of elements on the timeline in Group 1. $\mathrm{M}+\mathrm{A}$ is the number of milestones plus actions; $\mathrm{O}-\mathrm{B}$ is the number of opportunities minus barriers.

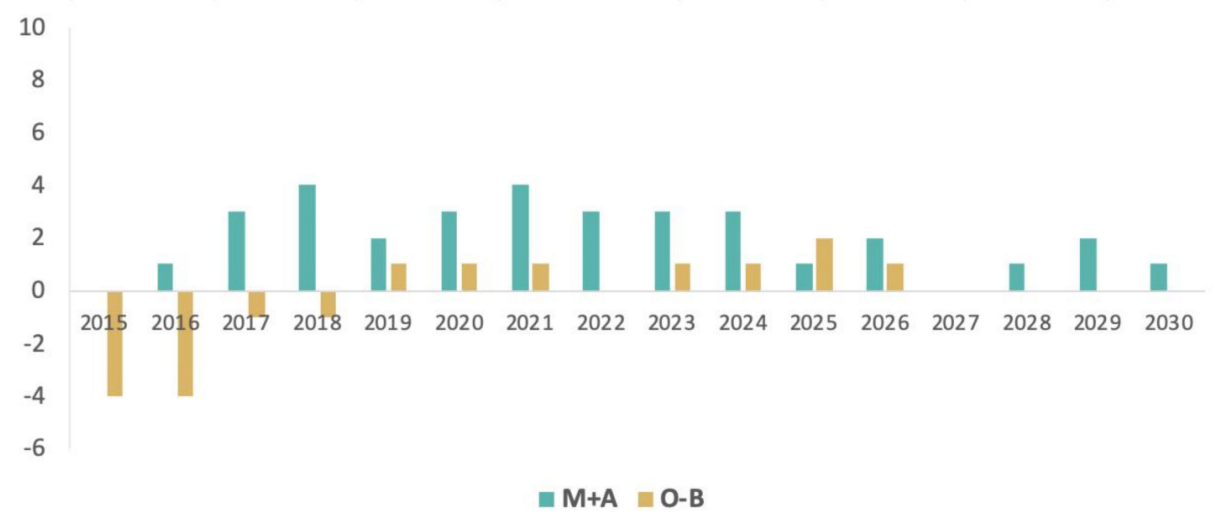

Figure 2. Balance of elements on the timeline in Group 2. $\mathrm{M}+\mathrm{A}$ is the number of milestones plus actions; $\mathrm{O}-\mathrm{B}$ is the number of opportunities minus barriers. 
The number of links in both maps are similar, 51 in Group 1 and 52 in Group 2. Both groups show a high percentage of total links being between milestones and actions ( $67 \%$ and $44 \%$ respectively) (Table 5), showing the direct link between actions and milestone achievement. However, the more dispersed effects of milestones achieving milestones are noted by only $10 \%$ of all links being between these elements in Group 1 and 29\% in Group 2.

Table 5. Links between elements.

\begin{tabular}{ccccc}
\hline \multirow{2}{*}{ Link } & \multicolumn{2}{c}{ Group 1 } & \multicolumn{2}{c}{ Group 2 } \\
\cline { 2 - 5 } & Total & \% & Total & \% \\
\hline Action with Action & 9 & 18 & 12 & 23 \\
\hline Milestone with Milestone & 5 & 10 & 15 & 29 \\
\hline Milestone with Actions & 34 & 67 & 23 & 44 \\
\hline Element with Objective & 3 & 6 & 2 & 4 \\
\hline Total & 51 & 100 & 52 & 100 \\
\hline
\end{tabular}

The number of connections that a year has in the future years implies the importance of that year in the backcast. For Group 1 years 2019, 2020 and 2026 have the highest influence in the flow of the process (Figure A1). In the case of Group 22018 and 2020 are the most influential ones (Figure A2).

\subsection{Milestones}

In total, 37 milestones were defined (19 in Group 1 and 18 in Group 2). In Group 1, the milestones were oriented towards technology, processing, products and crop management and breeding. In Group 2 , themes also included consumer awareness, organic agriculture supports, value chain establishment and the organoleptic properties of plant-proteins. Common milestone themes included:

- Increased funding for research and development of plant-proteins (2018)

- Availability of plant-protein products on the market (2019-2021)

- Establishment of value and supply (production-processing-retail) chains for protein-rich products (2024-2025)

- Development of new varieties of protein-rich crops (2026)

In the first five years of the timelines, milestones regarding funding, development facilities and product availability are seen in both groups. This would suggest that stakeholders think of these being the easiest to achieve due to their temporal proximity. More temporally distant milestones include increased awareness of plant-proteins, improved management and development of varieties.

\subsection{Barriers and Opportunities}

Across the two groups, 36 barriers and 33 opportunities were identified. The 19 barriers identified by Group 1 are diverse and include technological, agronomic and societal awareness. Of the 17 barriers identified by Group 2, distinct themes like product cost and scale were proposed as important impediments to achieve the objective. Across the groups three similar barrier themes were identified:

- High prices of protein-rich processed products may limit greater consumption (2018-2022)

- Low demand and a lack of knowledge of products also hinder consumption (2015-2020)

- Protein-rich product functional properties in terms of difficulty of protein extraction, lack of homogeneity in isolates and the organoleptic properties and anti-nutritional factors of represent processing barriers (2016-2025)

In total, 33 opportunities were identified (19 in Group 1 and 14 in Group 2). In Group 1, dietary changes, market development, sustainable benefits of plant-proteins, increased awareness and 
innovation were cited as opportunities. In Group 2, access to information, international collaborations and increased value in value chains were suggested. Although opportunities were distinct between the groups, repeated themes were evident:

- Health and environmental benefits (2020-2025)

- Dietary changes and increased consumer awareness (2021-2022)

- Marketability of products and improved access to information (2022)

\subsection{Actions}

In total, 39 actions (25 in Group 1 and 14 in Group 2) were defined. These actions are clustered across themes of consumer education, financial and information supports, lobbying and value chain restructuring. In Group 1, actions include increases in public supports, investments in breeding, creation of a plant lobby, consumer education, marketing and advertising and taxes of soya imports. In Group 2, actions included local supply chain development, certification, lobbying, biodiversity payments and labelling.

In total, 6 common actions were defined by participants (Figure 3). Despite the commonality of these actions, their voted importance was quite different. The development of local supply chains, increased consumer information, increases in funding for research and creation of a plant-protein lobby were voted as the most important (Figure 3). Furthermore, it is interesting to note the creation of a plant-protein lobby, which in both backcasts was set for the period 2020-21. This implies the perceived urgency for the need of a concerted and organized effort to include plant-proteins in political decision making and the need for a counter-point to the perceived power of the meat and dairy lobbies (identified as barriers).

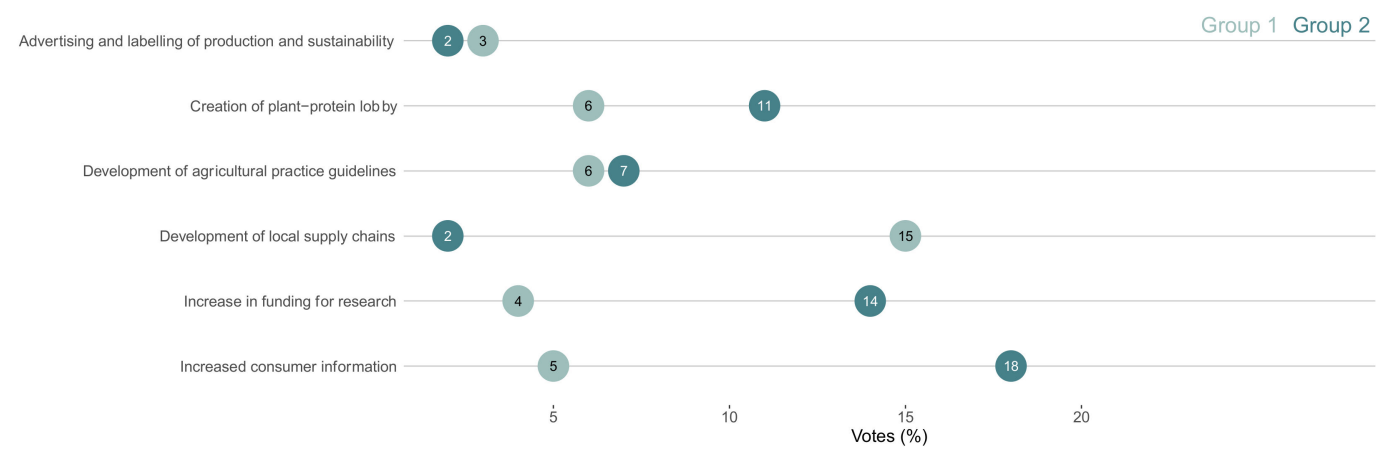

Figure 3. Actions needed to attain the desirable end-point from the backcasts. Most important actions identified by proportion of participants who voted for each. Only common actions across both groups are displayed in $\%$ of votes.

\subsection{Strategies}

In total, 13 strategies (7 in Group 1 and 6 in Group 2) linking milestones with actions were developed (different colored arrows in Figures 4 and 5). The strategies are presented from right to left, with the goal on the right and the stepwise milestones and actions needed from 2030 back to 2015 to attain the objective. These strategies are diverse and range from agricultural research and development, policy supports and consumer education. A number of these strategies are complex, requiring a number of actions and milestones before achieving the objective (e.g., Agricultural Research and Development and Marketing and Labelling of Figure 4; Consumer Education and Awareness and Development and Support of Supply and Value Chains of Figure 5), countered by a number of more simple strategies (e.g., Crop Management and Guidelines of Figure 4 and Agricultural Research of Figure 5). It is interesting to note that the groups perceived the strategy of Agricultural Research differently, one considering it complex, the other more simplistic. 
From Figures 4 and 5 it is evident that these strategies are similar not only in their content but also in the timelines for implementation. The similarity across the groups suggest that participants in both groups saw, in general terms, similar pathways of moving towards a more sustainable future. In both groups, the need for funding and support of protein products appear to be a key step in each of the strategies and for achieving the desired goal.

Following the workshop, 4 robust strategies for achieving the goal of increasing plant-protein production by $25 \%$ and increasing consumption by $10 \%$ were identified:

\subsubsection{Robust Strategy 1: Agricultural Research and Development}

Increased investment in research ( 2018-22) for crop breeding ( 2022) is implemented to improve protein-rich plant varieties for improved disease resistance ( 2023) and higher yields ( 2027), making these crops more attractive to farmers. Improved crop varieties result in increases in area dedicated to protein-rich crops across the EU ( 2028). Expansion of new cultivars is dependent upon information and support for agricultural training ( 2024). Means for achieving these increases in funding would be through the development of a protein-crop lobby ( 2019).

\subsubsection{Robust Strategy 2: Development and Support of Supply and Value Chains}

Formation of local supply chains ( 2019) encourage creation of value chains for protein-rich crops (2024-26) and expansion in protein-rich crop area ( 2028). The establishment and consolidation of these chains are supported and encouraged by supports for local protein-crop and organic production (2023-24), as well as through supports from the future reform of Common Agricultural Policy (CAP) ( 2027).

\subsubsection{Robust Strategy 3: Consumer Education and Awareness}

Advertising is expanded to increase exposure of protein-rich crop products ( 2019), with labelling improved ( 2019) to increase consumer information ( 2019-21). Improved consumer education ( 2021) is supported by dissemination of educational media to improve understanding of consumption and production benefits. Increased exposure to products and information drives greater consumption ( 2023) and acceptance ( 2025) of novel plant-based products.

\subsubsection{Robust Strategy 4: Policy Supports}

The formation of a protein-crop lobby ( 2019) would encourage greater national public (agricultural) policy supports ( 2022-24) directed towards protein-rich crops, leading to increased supports from the CAP ( 2027). This results in a competitive protein crop market ( 2028) and increases in areas dedicated to protein crops ( 2029). Further support mechanisms are used to increase taxes on imported soya ( 2026) and establish protective taxes to encourage greater use of EU-produced raw materials ( 2023). Policies are also implemented to increase prices of animal protein products ( 2025). 


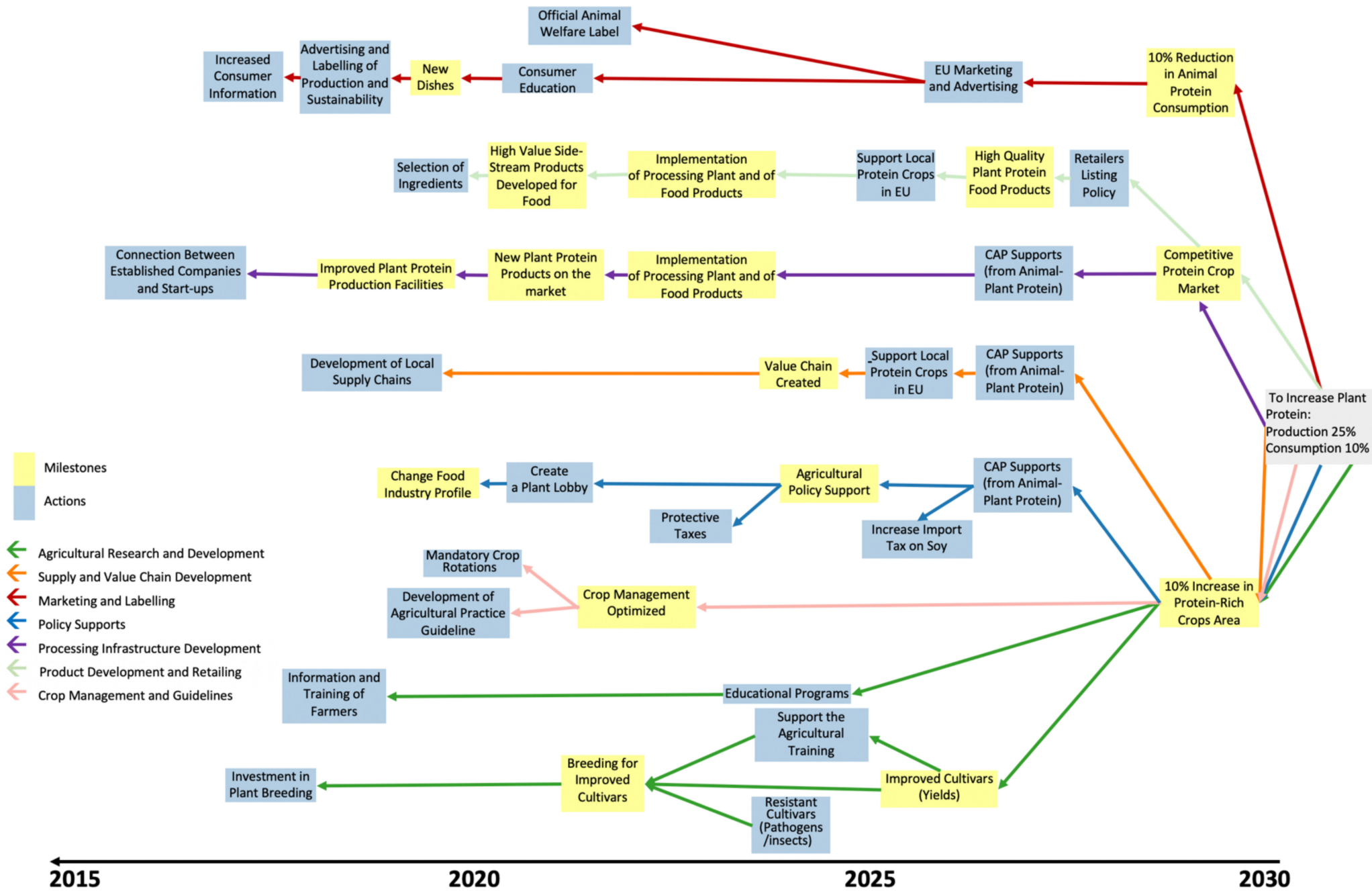

Figure 4. Group 1's strategies for moving towards sustainable protein future. 


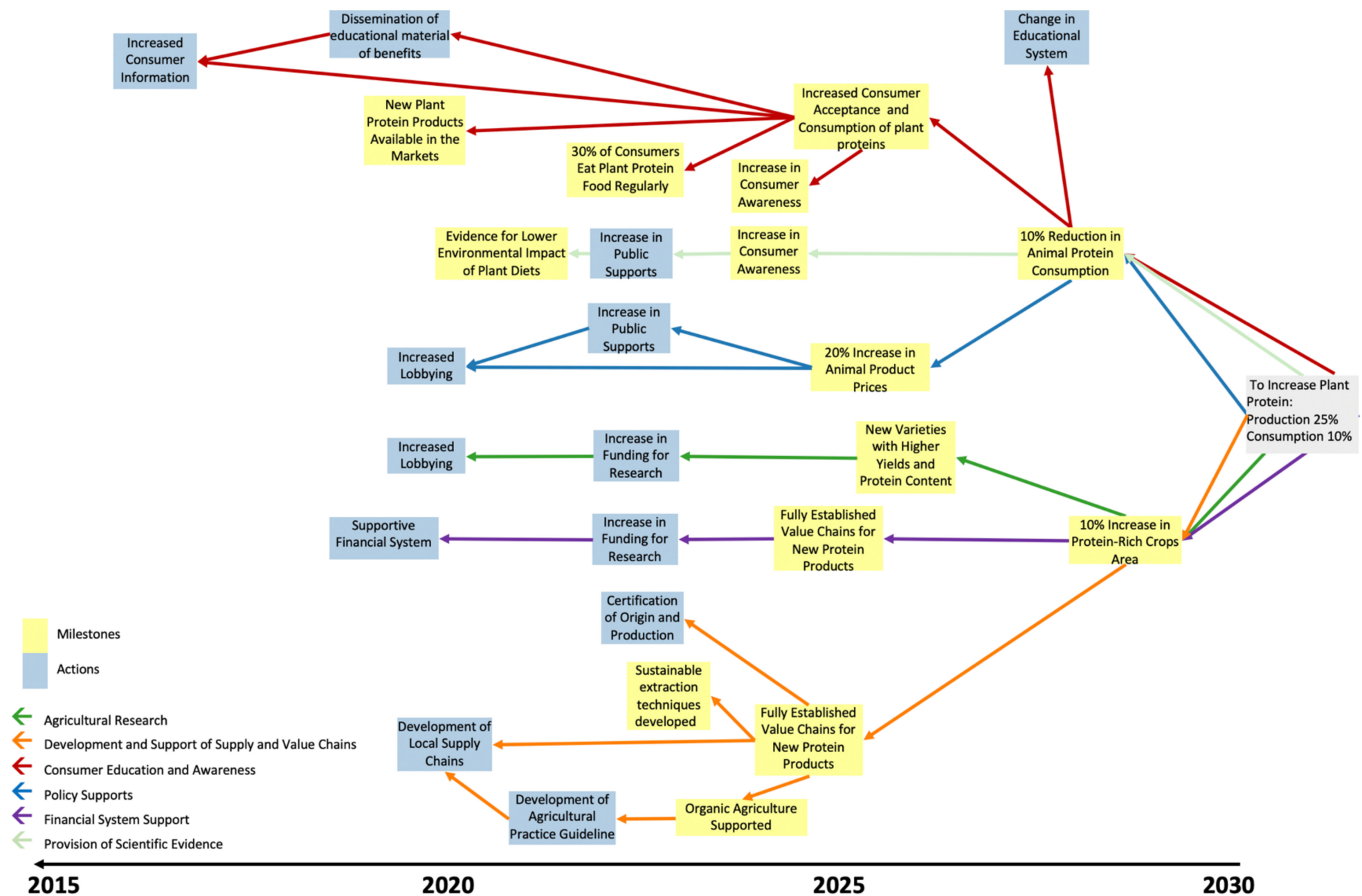

Figure 5. Group 2's strategies for moving towards sustainable protein future. 


\section{Discussion}

We performed a participatory backcasting exercise to identify and explore potential strategies for enabling sustainable European dietary futures, with four robust strategies identified. The constituent parts of these strategies largely echo findings of the literature of sustainable dietary futures but formalize them into coherent and temporally mapped pathways.

These normative strategies outline the need for greater production of plant-proteins in the EU. To do so, stakeholders stressed that formal investments in agricultural research should become a focus of future EU policies and could liberate protein-rich crop production. Particular attention is needed on investing in breeding programs to develop higher yielding and resistant protein-rich crop varieties. Such a suggestion is not without precedence within recent EU agricultural policies, where focused research investments were highly successful in stimulating pea production [44]. The co-benefits of such a policy could be wide-ranging and could help to address the agricultural barriers that currently affect legume production in Europe [45].

However, greater production of plant-proteins would not be sufficient to guarantee their availability nor their affordability for the general public. Stakeholders suggested that the focus of EU policies should also shift towards supporting the supply and value chains of protein-rich crops. Magrini et al. [44] outlines the inhibitory effects of incomplete supply chains for crops such as legumes, a point reflected in the workshop and from the authors' experiences in Spain. Etemadi et al. [6] evidences the benefits of complete and well-resourced value chains, highlighting how investments in value chains can contribute to consumption increases. Henchion et al. [46] argues that the commercial production of novel proteins requires the establishment of new value chains capable of minimizing production costs and risks. This could contribute to overcoming a major barrier identified by the stakeholders-the high price of protein-rich processed products. This barrier follows that of previous studies [47], who identified that healthier foods are likely unaffordable for low income populations. A shift to healthier diets may therefore require higher incomes, nutritional assistance and lower prices, representing considerable social and economic transformations. In this context, Henchion et al. [46] stresses the necessity of developing new initiatives to involve wider stakeholders and key value chain actors, not traditionally working together, to support the aforementioned transformations. Stakeholders insisted the crucial role of multi-scale governments (regional-supra national) for achieving such transformations. Voisin et al. [48] demonstrates previous governmental successes of supply chain supports, through creation of niche markets and labelling.

A decade after Schneider [49] posited that a lack of information of protein-rich crops had limited their production and consumption, de Bakker and Dagevos [50] noted the continued need for consumer education concerning plant-based products. Awareness of animal products' environmental impacts remains low amongst western consumers [51]. According to stakeholders, this lack of information continues to affect EU consumers. Ritchie et al. [8] states that without movement in consumer attitudes concerning animal-based products, consumption shifts are unlikely. Stakeholders noted and addressed these concerns stating that to reduce animal product consumption, increase animal replacement products' acceptance and shift towards greater plant protein consumption, would require EU-scale improvements in consumer education and access to and availability of, information. There continues to be a common notion amongst the general public that healthier diets may be unpalatable, low in variety and may be time intensive [31]. According to stakeholders, to address this misinformation the EU must step in and develop educational policies as a conduit for encouraging public opinion and consumption changes. Historically, governments have had policy successes in encouraging and promoting consumption shifts through educational activities [52]. Wellesley et al. [53] establishes that the general public expect governmental leadership to reduce the consumption of unhealthy products. Stakeholders suggest that marketing campaigns, which follow information and education campaigns, coupled with improved labelling and exposure to novel products, could assist in shifting consumer perceptions and increase awareness of the environmental and health impacts of animal products. 
Increases in public supports and implementation of taxes is another potential strategy presented for encouraging sustainable dietary changes. To increase production of protein-rich crops stakeholders noted that national or supra national agricultural policy supports were required. This is not without antecedence, where CAP supports have had direct and positive impacts upon EU legume cropping area [10]. Stakeholders reinforce the continued need of these supports for encouraging EU production of protein-rich crops. Stakeholders also stressed the need for taxation upon non-EU produced protein-rich crops, like soya, supporting calls from Wellesley et al. [53]. Protective taxes to encourage use of local raw protein-rich materials in plant-based products was also suggested as an enabling mechanism for transition. However, such protectionist taxation could have international trade implications, considering the EU's global trade agreements. Stakeholders summarized that application of taxes on animal-based products could also be used to reduce consumption. This is in line with calls from the literature for such measures (e.g., Springmann et al. [54]). Nordgren [55] argues the wide-ranging benefits of taxing meat consumption, with Springmann et al. [54] noting the benefits of carbon intensity related taxation, coupled with subsidies for food groups with positive health and environmental impacts. Saxe et al. [56], however, cautions the likely political, industrial and social opposition to such a strategy.

Although these strategies are defined individually, it is evident that their application in the real-world could not be mutually exclusive, being in many cases interdependent and complementary. For example, lobbying for greater supports for plant proteins and increased investment in research may be far more successful with greater citizen awareness and interest in their benefits. Improved consumer education would also encourage the completion of the supply chains, as farmers and companies would recognize the benefits of following consumer demands. Proposed policy suggestions could be considered individually or as part of a meta-strategy, taking advantage of their interconnectedness, to encourage a series of a virtuous circles towards more sustainable futures. Sachs et al. [57] calls this meta-strategy a 'sustainable food transformation' and argues that to achieve it, interventions should be pursued in an integrated manner. In line with our results, the strategies identified by Sachs et al. [57], to operationalize this transformation would require deep structural changes, strong government action and the mobilization of stakeholders. Our findings and those of Willett et al [2] and Gerten et al. [58] suggest that it is crucial that adoption of less resource-intensive diets occurs in the upcoming decade. Stakeholders perceive that, in the next years, we will be facing more opportunities than barriers and a high number of actions and milestones, which may contribute to accelerate the EU protein transition up to 2030 .

Finally, this study has contributed to the extensive literature on dietary change by concretely detailing how shifts in diets and production could be achieved in the real world, where current trends are largely moving in an increasingly unsustainable direction. Through a participatory methodology we mapped the conditions required to transition towards a near-future Europe, where diets are more plant-based. We identified a suite of strategies that, if implemented, could shift the EU from its current pathways towards a more sustainable 2030. Encouragingly, these strategies in many cases were found to be robust across groups, which may point to their potential efficacy, if implemented. These stakeholder derived strategies could be combined with the dietary scenarios that dominate the literature, to develop more explicit scenarios, assisting policy making.

\section{Limitations}

This study is subject to some limitations. One shortcoming inherent to participatory backcasting exercises is that the proposed final objective is largely dependent on values and can therefore be potentially contested [59]. This can be mitigated when the topic addressed is of high political relevance [34], which is this is the case of the present study. Furthermore, working temporally backwards can be difficult for stakeholders [38]. Thinking backwards can be counterintuitive and requires high concentration, especially when end-points are chosen far into the future (25-50 years). 
This may diminish the inherent capacity of backcasting to deal with high uncertainty in distant situations [60]. To address this, a more immediate goal period (2030) was selected.

In participatory backcasting, the distinction between milestones and actions is often described as too vague and dependent on the wording used [36]. Some examples that can be found in our study (e.g., 'optimizing crop management' as an action or 'crop management optimized' as a milestone) support this finding. Similarly, barriers and opportunities are in many cases difficult to distinguish (e.g., 'lack of public support' as barrier or 'public support' as opportunity) and can emerge as relevant items at different points in time (2015-2020 or 2020-2025). In these situations, good workshop facilitation is considered essential to clarify items, guide discussions and ensure an appropriate iterative process by looking at both the long and short term [38]. The authors tried to minimize these problems acting as facilitators due to their long experience in organizing, implementing and facilitating stakeholder workshops [61].

Another critical aspect common to participatory backcasting is time constraint. As time is limited in the workshops, the backcasts produced usually do not reach the level of detail that is needed to be used directly into decision-making processes [36]. In the present study, there was not enough time to address important issues, such as responsibility, costs, impacts or implementation procedures. In subsequent workshops, these issues should be analyzed, along with mutual influences between steps and strategies.

\section{Conclusions}

This study aimed to inform policymakers and the interested general public through the development of potential strategies and required actions to move towards a more sustainable dietary future in the EU. We used participatory backcasting to identify actions and develop strategies to transition EU protein-rich food production and consumption by 2030. Strategies developed revolved around increased funding for research, development and support of local supply chains, consumer education and awareness building and policy supports. These proposed strategies present a step-wise, time considerate and stakeholder derived conduit to a desirable future. Many of the developed strategies were dominated by actions required immediately, reinforcing the urgent need for actions to achieve necessary dietary changes and therefore avoid the health and environmental impacts of continuation of current dietary trends. This article complements previous studies that elaborate on the benefits of dietary shifts by enhancing understanding of near future barriers and opportunities, whilst providing stakeholder-based policy suggestions for encouraging sustainable dietary and production shifts. This study is, to our knowledge, the first to concretely detail how shifts in diets and production could be achieved in a real-world European context. The outputs of these stakeholder derived strategies could be combined with the dietary scenarios, that dominate the literature, to develop more temporally explicit models, to assist policy making and future scoping. Further, we propose as a next step, that further workshops should be performed, with a wider diversity of stakeholders (e.g., consumer groups), not only to validate the current strategies but to generate more detailed strategies. This would offer a greater learning opportunity for a wider selection of interest groups and would result in the development of highly structured and detailed strategies to be presented to policymakers.

Author Contributions: Conceptualization, I.B.-G. and C.V.-O.; Methodology, R.M., I.B.-G. and C.V.-O.; Formal Analysis, R.M., I.B.-G., C.V.-O. and A.M.T.; Investigation, R.M., I.B.-G. and C.V.-O.; Data Curation, R.M.; Writing-Original Draft Preparation, R.M., I.B.-G., C.V.-O. and A.M.T.; Visualization, R.M.; Funding Acquisition, C.V.-O. All authors have read and agreed to the published version of the manuscript.

Funding: This research was funded by the European Union Horizon 2020 Programme (H2020-SFS-2014-2), under grant agreement number. 635727-2 `Development of high quality food protein from multi-purpose crops through optimized, sustainable production and processing methods' (PROTEIN2FOOD) and the Universidad Politécnica de Madrid under grant number AL16-PID-9. This work was also supported by the Universidad Politécnica de Madrid and their programme for funding doctoral students. 
Acknowledgments: The authors would like to thank members of the PROTEIN2FOOD project for their inputs. They would also like to highlight and thank the stakeholders of the workshop for their time and invaluable contributions.

Conflicts of Interest: The authors declare no conflict of interest.

\section{Appendix A}

Table A1. Group 1 number of connections across years.

\begin{tabular}{|c|c|c|c|c|c|c|c|c|c|c|c|c|c|c|c|}
\hline CONECTIONS & 2016 & 2017 & 2018 & 2019 & 2020 & 2021 & 2022 & 2023 & 2024 & 2025 & 2026 & 2027 & 2028 & 2029 & 2030 \\
\hline 2016 & 0 & & & & & & & & & & & & & & \\
\hline 2017 & 1 & 1 & & & & & & & & & & & & & \\
\hline 2018 & 0 & 2 & 0 & & & & & & & & & & & & \\
\hline 2019 & 0 & 1 & 0 & 2 & & & & & & & & & & & \\
\hline 2020 & 0 & 1 & 0 & 1 & 0 & & & & & & & & & & \\
\hline 2021 & 0 & 0 & 0 & 3 & 1 & 0 & & & & & & & & & \\
\hline 2022 & 0 & 0 & 0 & 1 & 2 & 0 & 0 & & & & & & & & \\
\hline 2023 & 0 & 0 & 0 & 0 & 1 & 2 & 0 & 0 & & & & & & & \\
\hline 2024 & 0 & 0 & 0 & 1 & 0 & 1 & 0 & 2 & 1 & & & & & & \\
\hline 2025 & 0 & 0 & 0 & 0 & 1 & 0 & 2 & 0 & 0 & 0 & & & & & \\
\hline 2026 & 0 & 0 & 0 & 0 & 0 & 1 & 2 & 1 & 0 & 2 & 0 & & & & \\
\hline 2027 & 0 & 0 & 0 & 0 & 0 & 1 & 0 & 1 & 1 & 0 & 3 & 0 & & & \\
\hline 2028 & 0 & 0 & 0 & 0 & 0 & 0 & 0 & 0 & 0 & 0 & 1 & 2 & 1 & & \\
\hline 2029 & 0 & 0 & 0 & 0 & 0 & 0 & 0 & 0 & 2 & 0 & 2 & 1 & 1 & 0 & \\
\hline 2030 & 0 & 0 & 0 & 0 & 0 & 0 & 0 & 0 & 0 & 0 & 0 & 0 & 1 & 2 & 0 \\
\hline TOTAL & 1 & 5 & 0 & 8 & 5 & 5 & 4 & 4 & 4 & 2 & 6 & 3 & 3 & 2 & 0 \\
\hline
\end{tabular}

Table A2. Group 2 number of connections across years.

\begin{tabular}{|c|c|c|c|c|c|c|c|c|c|c|c|c|c|c|c|}
\hline CONECTIONS & 2016 & 2017 & 2018 & 2019 & 2020 & 2021 & 2022 & 2023 & 2024 & 2025 & 2026 & 2027 & 2028 & 2029 & 2030 \\
\hline 2016 & 0 & & & & & & & & & & & & & & \\
\hline 2017 & 0 & 0 & & & & & & & & & & & & & \\
\hline 2018 & 0 & 1 & 1 & & & & & & & & & & & & \\
\hline 2019 & 0 & 2 & 2 & 0 & & & & & & & & & & & \\
\hline 2020 & 0 & 0 & 0 & 1 & 1 & & & & & & & & & & \\
\hline 2021 & 0 & 0 & 0 & 0 & 2 & 0 & & & & & & & & & \\
\hline 2022 & 0 & 0 & 2 & 0 & 1 & 1 & 0 & & & & & & & & \\
\hline 2023 & 0 & 0 & 0 & 0 & 0 & 2 & 0 & 0 & & & & & & & \\
\hline 2024 & 0 & 0 & 1 & 1 & 1 & 2 & 1 & 3 & 1 & & & & & & \\
\hline 2025 & 0 & 1 & 2 & 1 & 1 & 0 & 1 & 0 & 1 & 0 & & & & & \\
\hline 2026 & 0 & 0 & 0 & 0 & 1 & 0 & 1 & 0 & 1 & 0 & 0 & & & & \\
\hline 2027 & 0 & 0 & 0 & 0 & 0 & 0 & 0 & 0 & 0 & 0 & 0 & 0 & & & \\
\hline 2028 & 0 & 0 & 0 & 0 & 0 & 0 & 1 & 0 & 0 & 0 & 0 & 0 & 0 & & \\
\hline 2029 & 0 & 2 & 1 & 0 & 0 & 0 & 0 & 0 & 1 & 2 & 3 & 0 & 1 & 0 & \\
\hline 2030 & 0 & 0 & 0 & 0 & 0 & 0 & 0 & 0 & 0 & 0 & 0 & 0 & 0 & 2 & 0 \\
\hline TOTAL & 0 & 6 & 9 & 3 & 7 & 5 & 4 & 3 & 4 & 2 & 3 & 0 & 1 & 2 & 0 \\
\hline
\end{tabular}




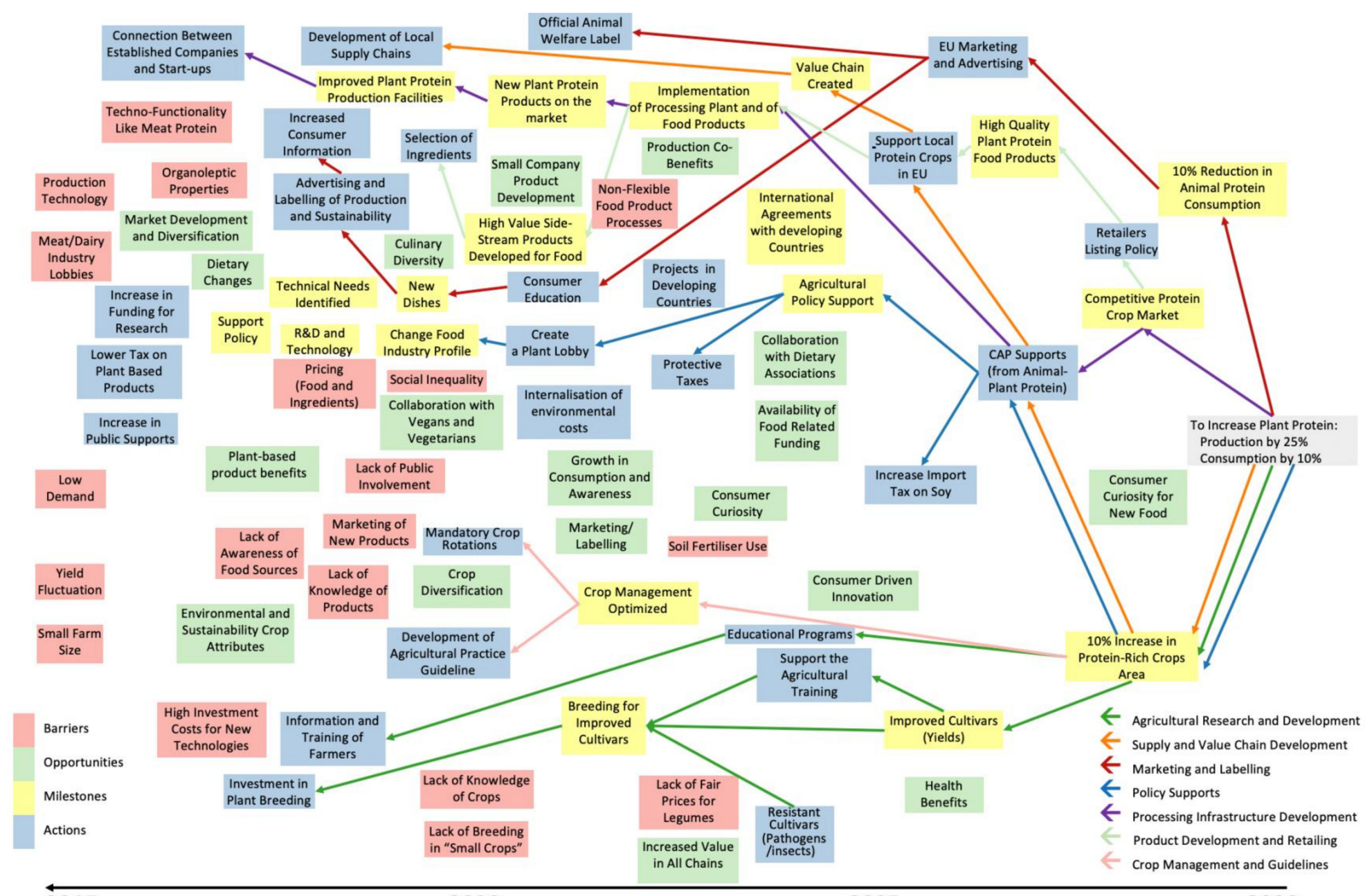

2015

Figure A1. Backcast from Group 1. Seven strategies imposed. 


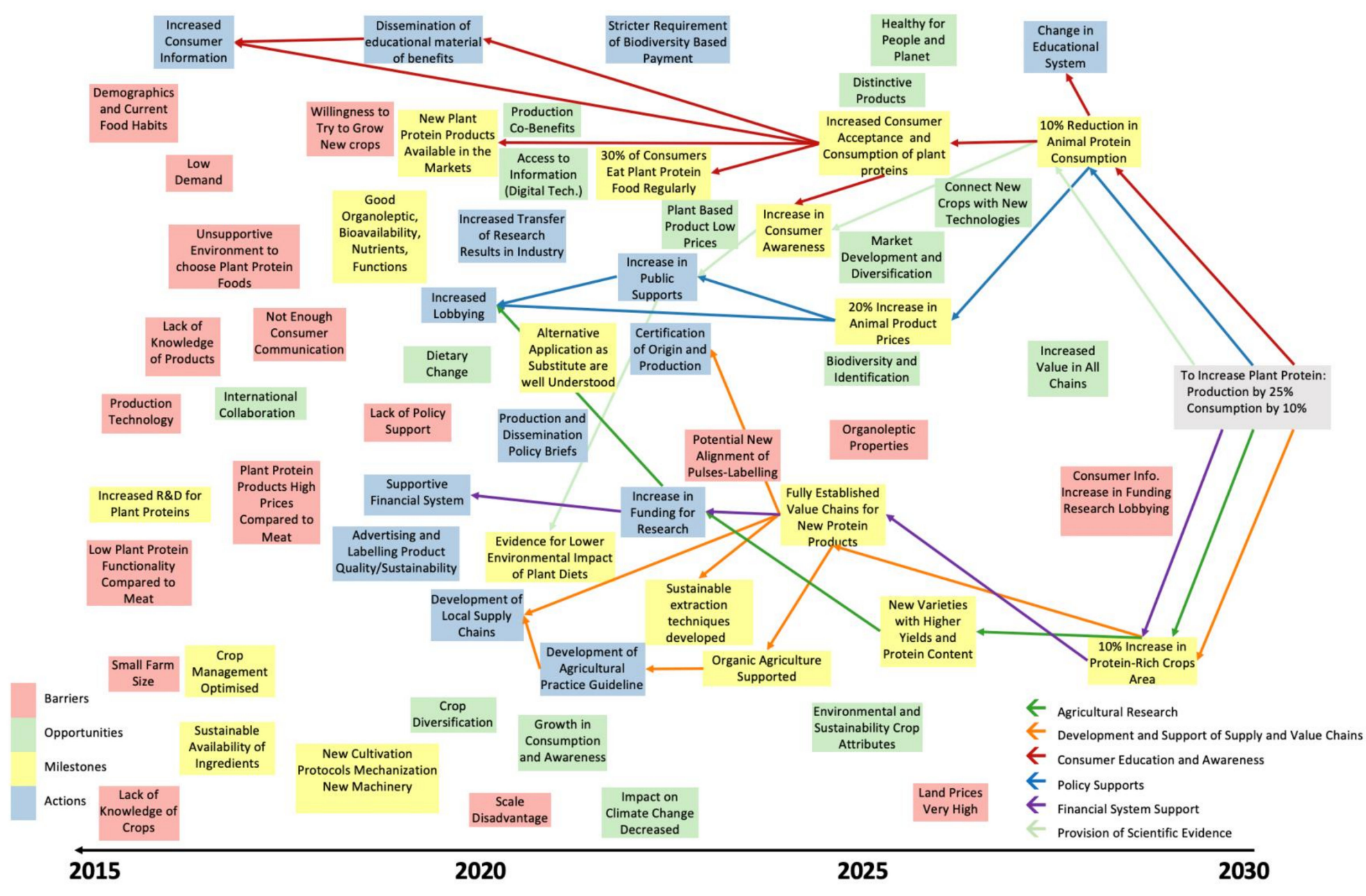

Figure A2. Backcast from Group 2. Six identified strategies imposed. 


\section{References}

1. Hallstrom, E.; Carlsson-Kanyama, A.; Borjesson, P. Environmentsal impacts of dietary change: A systematic review. J. Clean. Prod. 2015, 91,1-11. [CrossRef]

2. Willett, W.; Rockström, J.; Loken, B.; Springmann, M.; Lang, T.; Vermeulen, S.; Garnett, T.; Tilman, D.; DeClerck, F.; Wood, A.; et al. Food in the Anthropocene: The EAT-Lancet Commission on healthy diets from sustainable food systems. Lancet 2019. [CrossRef]

3. Machovina, B.; Feeley, K.J.; Ripple, W.J. Biodiversity conservation: The key is reducing meat consumption. Sci. Total Environ. 2015, 536, 419-431. [CrossRef] [PubMed]

4. Vermeulen, S.J.; Campbell, B.M.; Ingram, J.S.I. Climate change and food systems. Annu. Rev. Environ. Resour. 2012, 37, 195-222. [CrossRef]

5. Aiking, H.; de Boer, J. The next protein transition. Trends Food Sci. Technol. 2018. [CrossRef]

6. Etemadi, A.; Sinha, R.; Ward, M.H.; Graubard, B.I.; Inoue-Choi, M.; Dawsey, S.M.; Abnet, C.C. Mortalitiy from different causes associated with meat, heme iron, nitrates and nitrites in the NIH-AARP diet and health study: Population based cohort study. BMJ 2017, 357, j1957. [CrossRef]

7. Bouvard, V.; Loomis, D.; Guyton, K.Z.; Grosse, Y.; Ghissassi, F.E.; Benbrahim-Tallaa, L.; Guha, N.; Mattock, H.; Straif, K. Carcinogenicity of consumption of red and processed meat. Lancet Oncol. 2015, 16, 1599-1600. [CrossRef]

8. Ritchie, H.; Reay, D.S.; Higgins, P. The impact of global dietary guidelines on climate change. Glob. Environ. Chang. 2018, 49, 46-55. [CrossRef]

9. Sans, P.; Combris, P. World meat consumption patterns: An overview of the last fifty years (1961-2011). Meat Sci. 2015, 109, 106-111. [CrossRef]

10. Manners, R. Drivers, Impacts and Policy Options to Address Land Use Changes at Multiple Scales: Implications of Food Production, Rural Livelihoods and Ecosystem Conservation. Ph.D. Thesis, Universidad Politécnica de Madrid, Madrid, Spain, 4 December 2018.

11. Poore, J.; Nemecek, T. Reducing food's environmental impacts through producers and consumers. Science 2018, 360, 987-992. [CrossRef]

12. Bonhommeau, S.; Dubroca, L.; Le Pape, O.; Barde, J.; Kaplan, D.M.; Chassot, E.; Nieblas, A.-E. Eating up the world's food web and the human trophic level. Proc. Natl. Acad. Sci. USA 2013, 110, 20617-20620. [CrossRef] [PubMed]

13. Kastner, T.; Rivas, M.J.I.; Koch, W.; Nonhebel, S. Global changes in diets and the consequences for land requirements for food. Proc. Natl. Acad. Sci. USA 2012, 109, 6868-6872. [CrossRef]

14. Vranken, L.; Avermaete, T.; Petalios, D.; Mathijs, E. Curbing global meat consumption: Emerging evidence of a second nutrition transition. Environ. Sci. Policy 2014, 39, 1-12. [CrossRef]

15. Bailey, R.; Froggatt, A.; Wellesley, L. Livestock-Climate Change's Forgotten Sector Global Public Opinion on Meat and Dairy Consumption; Chatham House Report; Chatham House: London, UK, 2014.

16. Ranganathan, J.; Vennard, D.; Waite, R.; Dumas, P.; Lipinski, B.; Searchinger, T. Shifting Diets for a Sustainable Food Future; World Resources Institute Working Paper; World Resources Institute: Washington, DC, USA, 2016.

17. Bodirsky, B.L.; Rolinski, S.; Biewald, A.; Weidnle, I.; Popp, A.; Lotze-Campen, H. Global food demand scenarios for the 21st century. PLoS ONE 2015, 10, e0139201. [CrossRef] [PubMed]

18. Springmann, M.; Godfray, H.C.J.; Rayner, M.; Scarborough, P. Analysis and valuation of the health and climate change cobenefits of dietary change. Proc. Natl. Acad. Sci. USA 2016, 113, 4146-4151. [CrossRef] [PubMed]

19. IPCC. Climate Change and Land-An IPCC Special Report on Climate Change, Desertification, Land Degradation, Sustainable Land Management, Food Security and Greenhouse Gas Fluxes in Terrestrial Ecosystems; Summary for Policymakers; IPCC: Geneva, Switzerland, 2019.

20. Harwatt, H.; Sabaté, J.; Eshel, G.; Soret, S.; Ripple, W. Substituting beans for beef as a contribution toward US climate change targets. Clim. Chang. 2017, 143, 261-270. [CrossRef]

21. Springmann, M.; Clark, M.; Mason-D'Croz, D.; Wiebe, K.; Bodirsky, B.L.; Lassaletta, L.; de Vries, W.; Vermeulen, S.J.; Herrero, M.; Carlson, K.M.; et al. Options for keeping the food system within environmental limits. Nature 2018, 562, 519-525. [CrossRef]

22. Cassidy, E.S.; West, P.C.; Gerber, J.S.; Foley, J.A. Redefining agricultural yields: From tonnes to people nourished per hectare. Environ. Res. Lett. 2013, 8, 34015. [CrossRef] 
23. Erb, K.-H.; Lauk, C.; Kastner, T.; Mayer, A.; Theurl, M.C.; Haberly, H. Exploring the biophysical option space for feeding the world without deforestation. Nat. Commun. 2016, 7, 11382. [CrossRef]

24. De Boer, J.; Aiking, H. Pursuing a low meat diet to improve both health and sustainability: How can we use the frame that shape our meals. Ecol. Econ. 2017, 142, 238-248. [CrossRef]

25. Wirsenius, S.; Azar, C.; Berndes, G. How much land is needed for global food production under scenarios of dietary changes and livestock productivity increases in 2030? Agric. Syst. 2010, 103, 621-638. [CrossRef]

26. Beverland, M.B. Mainstreaming plant-based diets in developed economies. J. Macromark. 2014, 34, 369-382. [CrossRef]

27. Godfray, H.C.J.; Aveyard, P.; Garnett, T.; Hall, J.W.; Key, T.J.; Lorimer, J.; Pierrehumbert, R.T.; Scarborough, P.; Springmann, M.; Jebb, S.A. Meat consumption, health and the environment. Science 2018, 361, 8036-8075. [CrossRef] [PubMed]

28. Graça, J. Towards an integrated approach to food behavior: Meat consumption and substitution, from context to consumers. Psychol. Community Health 2016, 2, 152-159. [CrossRef]

29. Rosenfeld, D.L. The psychology of vegetarianism: Recent advance and future directions. Appetite 2018, 131, 125-138. [CrossRef]

30. Bianchi, F.; Dorsel, C.; Garnett, E.; Aveyard, P.; Jebb, S.A. Interventions targeting conscious determinants of human behavior to reduce the demand for meat: A systematic review with qualitative comparative analysis. Int. J. Behav. Nutr. Phys. 2018, 15, 102. [CrossRef]

31. Graça, J.; Godinho, C.A.; Truninger, M. Reducing meat consumption and following plant-based diets: Current evidence and future directions to inform integrated transitions. Trends Food Sci. Technol. 2019, 91, 380-390. [CrossRef]

32. Börjeson, L.; Höjer, M.; Dreborg, K.-H.; Ekvall, T.; Finnveden, G. Scenario types and techniques: Towards a user's guide. Futures 2006, 38, 723-739. [CrossRef]

33. Robinson, J. Energy backcasting: A proposed method of policy analysis. Energy Policy 1982, 10, 337-344. [CrossRef]

34. Dreborg, K.-H. Essence of backcasting. Futures 1996, 28, 813-828. [CrossRef]

35. Quist, J.; Vergragt, P. Past and future of backcasting: The shift to stakeholder participation and a proposal for a methodological framework. Futures 2006, 38, 1027-1045. [CrossRef]

36. Kok, K.; van Vliet, M.; Barlund, I.; Dubel, A.; Sendzimir, J. Combining participative backcasting and exploratory scenario development: Experiences from the SCENES project. Technol. Soc. Chang. 2011, 78, 835-851. [CrossRef]

37. Salter, J.; Robinson, J.; Wiej, A. Participatory methods of integrated assessment- a review. Wires Clim. Chang. 2010, 1, 697-717. [CrossRef]

38. Van Vliet, M.; Kok, K. Combining backcasting and exploratory scenarios to develop robust water strategies in face of uncertain futures. Mitig. Adapt. Strateg. Glob. Chang. 2015, 20, 43-74. [CrossRef]

39. Swart, R.J.; Raskin, P.; Robinson, J.B. The problem of the future: Sustainability science and scenario analysis. Glob. Environ. Chang. 2004, 14, 137-146. [CrossRef]

40. Nassauer, J.I.; Corry, R.C. Using normative scenarios in landscape ecology. Landsc. Ecol. 2004, 19, 343-356. [CrossRef]

41. Latapy, M.; Magnien, C.; del Vecchio, N. Basic notions for the analysis of large two-mode networks. Soc. Netw. 2008, 30, 31-48. [CrossRef]

42. Wu, C.W. Algebraic connectivity of directed graphs. Linear Multilinear A 2005, 53, 203-223. [CrossRef]

43. Johnston, J.L.; Fanzo, J.C.; Cogill, B. Understanding sustainable diets: A descriptive analysis of the determinants and processes that influence diets and their impact on health, food security and environmental sustainability. Adv. Nutr. 2014, 5, 418-429. [CrossRef]

44. Magrini, M.B.; Anton, M.; Cholez, C.; Corre-Hellou, G.; Duc, G.; Jeuffroy, M.-H.; Meynard, J.-M.; Pelzer, E.; Voisin, A.-S.; Walrand, S. Why are grain-legumes rarely present in cropping systems despite their environmental and nutritional benefits? Analyzing lock-in in the French agrifood system. Ecol. Econ. 2016, 126, 152-162. [CrossRef]

45. Watson, C.A.; Reckling, M.; Preissel, S.; Bachinger, J.; Bergkvist, G.; Kuhlman, T.; Lindstöm, K.; Nemecek, T.; Topp, C.F.E.; Vanhatalo, A.; et al. Grain legume production and use in european agricultural systems. Adv. Agron. 2017, 144, 235-303. [CrossRef] 
46. Henchion, M.; Hayes, M.; Mullen, A.M.; Fenelon, M.; Tiwari, B. Future protein supply and demand: Strategies and factors influencing a sustainable equilibrium. Foods 2017, 6, 53. [CrossRef] [PubMed]

47. Hirvonen, K.; Bai, Y.; Headey, D.; Masters, W.A. Affordability of the EAT-lancet reference diet: A global analysis. Lancet Glob. Health 2020, 8, e59-e66. [CrossRef]

48. Voisin, A.S.; Guéguen, J.; Huyghe, C.; Jeuffroy, M.-H.; Magrini, M.-B.; Meynard, J.-M.; Mougel, C.; Pellerin, S.; Pelzer, E. Legumes for feed, food, biomaterials and bioenergy in Europe: A review. Agron. Sustain. Dev. 2014, 34, 361-380. [CrossRef]

49. Schneider, A.V.C. Overview of the market and consumption of pulses in Europe. Br. J. Nutr. 2002, 88, 243. [CrossRef] [PubMed]

50. de Bakker, E.; Dagevos, H. Reducing meat consumption in today's consumer society: Questioning the citizen-consumer gap. J. Agric. Environ. Ethics 2012, 25, 877-894. [CrossRef]

51. Lentz, G.; Connelly, S.; Mirosa, M.; Jowett, T. Gauging attitudes and behaviours: Meat consumption and potential reduction. Appetite 2018, 127, 230-241. [CrossRef]

52. Keats, S.; Wiggins, S. Future Diets: Implications for Agriculture and Food Prices; The Overseas Development Institute: London, UK, 2014.

53. Wellesley, L.; Happer, C.; Froggatt, A. Changing Climate, Changing Diets Pathways to Lower Meat Consumption; Chatham House Report; Chatham House: London, UK, 2015.

54. Springmann, M.; Mason-D'Croz, D.; Robinson, S.; Wiebe, K.; Godfray, H.C.J.; Rayner, M.; Scarborough, P. Mitigation potential and global health impacts from emissions pricing of food commodities. Nat. Clim. Chang. 2017, 7, 69-74. [CrossRef]

55. Nordgren, A. Ethical issues in mitigation of climate change: The option of reduced meat production and consumption. J. Agric. Environ. Ethics 2012, 25, 563-584. [CrossRef]

56. Saxe, H.; Larsen, T.M.; Mogensen, L. The global warming potential of two healthy Nordic diets compared with the average Danish diet. Clim. Chang. 2013, 116, 249-262. [CrossRef]

57. Sachs, J.D.; Schmidt-Traub, G.; Mazzucato, M.; Messner, D.; Nebojsa, N.; Rockström, J. Six transformations to achieve the sustainable development goals. Nat. Sustain. 2019, 2, 805-814. [CrossRef]

58. Gerten, D.; Heck, V.; Jägermeyr, J.; Bodirsky, B.L.; Fetzer, I.; Jalava, M.; Kummu, M.; Lucht, W.; Rockström, J.; Schaphoff, S.; et al. Feeding ten billion people is possible within four terrestrial planetary boundaries. Nat. Sustain. 2020. [CrossRef]

59. Robinson, J. Future subjunctive: Backcasting as social learning. Futures 2003, 35, 839-856. [CrossRef]

60. Vergragt, P.; Quist, J. Backcasting for sustainability: Introduction to the special issue. Technol. Forecast Soc. 2011, 78, 747-755. [CrossRef]

61. Blanco-Gutiérrez, I.; Manners, R.; Varela-Ortega, C.; Tarquis, A.; Martorano, L.G.; Toledo, M. Examining the sustainability and development challenge in agricultural-forest frontiers of the Amazon Basin. Nat. Hazards Earth Syst. Sci. 2019, in press. 